\title{
Alterations in pulmonary structure by elastase administration in a model of emphysema in mice is associated with functional disturbances
}

\author{
D. Vidal ${ }^{a, b}$, G. Fortunato ${ }^{a, c}$, W. Klein ${ }^{d, e, f}$, L. Cortizo ${ }^{a}$, J. Vasconcelos ${ }^{a, b}$, \\ R. Ribeiro-dos-Santos ${ }^{a, b}$, M. Soares ${ }^{a, b}$, S. Macambira ${ }^{a, b, g, *}$
}

a Laboratório de Engenharia tecidual e Imunofarmacologia, Centro de Pesquisas Gonçalo Moniz, Fundação Oswaldo Cruz, Salvador, BA, Brazil

b Centro de Biotecnologia e Terapia Celular, Hospital São Rafael, Salvador, BA, Brazil

c Programa de Pós-Graduação em Biotecnologia, Universidade Estadual de Feira de Santana, Feira de Santana, BA, Brazil

d Faculdade de Biologia, Instituto de Biologia, Universidade Federal da Bahia, Salvador, BA, Brazil

e Instituto de Biociências, Instituto Nacional de Ciência e Tecnologia em Fisiologia Comparada, UNESP, Rio Claro, SP, Brazil

${ }^{f}$ Departamento de Biologia, Faculdade de Filosofia, Ciências e Letras de Ribeirão Preto, Universidade de São Paulo, SP, Brazil

" Laboratório de Eletrofisiologia Cardíaca "Prof Antônio Paes de Carvalho", Instituto de Biofísica Carlos Chagas Filho,

Universidade Federal do Rio de Janeiro, RJ, Brazil

Received 6 July 2011; accepted 23 December 2011

Available online 17 March 2012

\section{KEYWORDS \\ Pulmonary \\ emphysema; \\ Ergometric test; \\ Porcine elastase; \\ C57Bl/6}

\begin{abstract}
Several experimental studies of pulmonary emphysema using animal models have been described in the literature. However, only a few of these studies have focused on the assessment of ergometric function as a non-invasive technique to validate the methodology used for induction of experimental emphysema. Additionally, functional assessments of emphysema are rarely correlated with morphological pulmonary abnormalities caused by induced emphysema. The present study aimed to evaluate the effects of elastase administered by tracheal puncture on pulmonary parenchyma and their corresponding functional impairment. This was evaluated by measuring exercise capacity in C57Bl/6 mice in order to establish a reproducible and safe methodology of inducing experimental emphysema. Thirty six mice underwent ergometric tests before and 28 days after elastase administration. Pancreatic porcine elastase solution was administered by tracheal puncture, which resulted in a significantly decreased exercise capacity, shown by a shorter distance run $(-30.5 \%)$ and a lower mean velocity $(-15 \%)$, as well as in failure to increase the elimination of carbon dioxide. The mean linear intercept increased significantly by $50 \%$ in tracheal elastase administration. In conclusion, application of elastase by tracheal function in C57Bl/6 induces emphysema, as validated by
\end{abstract}

\footnotetext{
* Corresponding author.

E-mail address: simone@bahia.fiocruz.br (S. Macambira).
}

0873-2159/\$ - see front matter @ 2011 Sociedade Portuguesa de Pneumologia. Published by Elsevier España, S.L. All rights reserved. 


\section{PALAVRAS-CHAVE}

Enfisema pulmonar; ensaio ergométrico; Elastase suína; C57Bl/6

morphometric analyses, and resulted in a significantly lower exercise capacity, while resulting in a low mortality rate.

(c) 2011 Sociedade Portuguesa de Pneumologia. Published by Elsevier España, S.L. All rights reserved.

\section{Alterações na estrutura pulmonar devido à administração de elastase num modelo de enfisema em ratos encontram-se associadas a distúrbios funcionais}

Resumo Vários estudos experimentais de enfisema pulmonar em modelos animais têm sido descritos na literatura científica. No entanto, apenas alguns destes estudos têm sido concentrados na avaliação da função ergométrica como técnica não-invasiva para validar a metodologia utilizada para a indução do enfisema experimental. Além disso, as avaliações funcionais de enfisema raramente se encontram correlacionadas com anomalias morfológicas pulmonares causadas por enfisema induzido. 0 presente estudo teve como objetivo avaliar os efeitos da elastase administrada por punção traqueal no parênquima pulmonar e a sua disfunção funcional correspondente. Esta foi avaliada através da medição da capacidade de exercício em ratos $\mathrm{C} 57 \mathrm{Bl} / 6$, de forma a estabelecer uma metodologia reprodutível e segura de induzir o enfisema experimental. Trinta e seis ratos foram submetidos a testes ergométricos antes e 28 dias após a administração de elastase. A solução de elastase pancreática suína foi administrada por punção traqueal, o que resultou numa diminuição significativamente da capacidade de exercício, demonstrada pela diminuição da distância percorrida (menos de 30,5\%) e por uma velocidade média inferior (menos de 15\%), assim como pela incapacidade de aumentar a eliminação de dióxido de carbono. A intersecção linear média aumentou significativamente em $50 \%$ na administração traqueal da elastase. Em conclusão, a aplicação de elastase por punção traqueal em ratos C57Bl/6 induz enfisema, conforme foi validado por análises morfométricas, e resultou numa capacidade de exercício significativamente mais baixa, embora se tenha obtido uma baixa taxa de mortalidade.

(c) 2011 Sociedade Portuguesa de Pneumologia. Publicado por Elsevier España, S.L. Todos os direitos reservados.

\section{Introduction}

Emphysema is a chronic obstructive pulmonary disease (COPD), limiting air flow during expiration, and is associated with an abnormal inflammatory response of the lungs to noxious particles or gases (mainly cigarette smoke). This disease is characterized by a permanent abnormal dilatation of alveolar spaces. The destruction of pulmonary parenchyma impairs alveolar gas exchange, compromising the physical capacity of a patient since it is associated with airflow limitations that are not fully reversible.

No therapy capable of reversing emphysematous tissue lesions is available to date and, in severe chronic stages the only treatment that remains is lung transplantation, representing a procedure with high levels of morbidity and mortality. Emphysema, together with other types of COPD, are responsible for more than $\mathbf{2 . 5}$ million deaths every year, representing the fifth leading cause of mortality in the world.

The severity of its pathology together with the lack of any effective treatment transforms emphysema into a great medical challenge. There is a need for studies aiming to understand the pathogenic cellular mechanisms causing tissue destruction in order to elucidate the disease and to open new therapeutic avenues. Another aggravator is the fact that a considerable variation exists in the course of the disease among different smokers. Only about $15 \%$ of smokers develop COPD. ${ }^{1,2}$

Animal models represent a fundamental instrument to correlate pre-clinical research with clinical studies. The experimental model allows the detailed investigation of different factors influencing emphysema. These factors include inflammatory cell recruitment, genetic background, abnormal matrix repair, lung cell apoptosis, and misbalance between apoptosis and replenishment of structural cells in the lung. Additional factors are research of potential therapeutic agents and strategies, such as administration of stem cells or different growth factors. ${ }^{3}$

Until now there are many experimental models of COPD, each of them with advantages and disadvantages. In reality, a number of approaches have been tried because until now none of them constitutes a model that exactly reproduces all phases of development and clinical features of emphysema or any other abnormalities that make up this clinical entity, the COPD. Other factor that affects the reproducibility of data is the differences in anatomical structure with respect to development, maturation, structural organization of respiratory branches, and constituent cells and vascularization. ${ }^{4}$ On the other side, some common characteristics can be observed between animal model and human disease. For example, rodents develop the phenomenon of metaplasia induced by reaction to injury, ${ }^{5}$ which is a frequently observed response to an insult in different organs in humans, such as in respiratory tract, urinary bladder, and esophagus.

The first animal model of emphysema was developed more than 40 years ago $^{6}$ and it was evoked in rats by intratracheal instillation of the plant proteinase papain. The experimental models of emphysema are continuously improving and became a research tool for 
several groups of scientists. These include enzyme airway administration model, ${ }^{7,8}$ tobacco smoking model, ${ }^{9,10}$ apoptosis induced emphysema by intratracheal instillation of activated caspase-3, ${ }^{11}$ AIAT deficient animals, ${ }^{12}$ natural mutants, ${ }^{13}$ knockout mice, ${ }^{14}$ and transgenic mice. ${ }^{15}$ Despite the model chosen all of them present restrictions. ${ }^{16-22}$

Taking these informations into account, in the present study we chose to reproduce human pulmonary emphysema in mouse model using intratracheal instillation of porcine pancreatic elastase because it is used for more than three decades and has been well characterized. ${ }^{29}$ Until now it is considered to be the most consistent and impressive model of airspace enlargement. ${ }^{30}$ This is due to the exposure of elastin fibers to porcine pancreatic elastase leading to acute lung inflammation and pulmonary parenchyma destruction. This model is very appropriate to investigate the relation between structure and function abnormalities characteristics of emphysema progression, as well as elucidated factors associated to these disturbances and collagen remodeling failure related to this pathology. ${ }^{31}$ This model was used to investigate and validate a new methodology to evaluate the dynamic lung mechanical function in experimental model of emphysema. ${ }^{32}$ The pathogenesis for emphysema includes many events such as inflammation, elastase, matrix metalloprotease imbalance, apoptosis, and oxidative stress, which are reproduced by elastase administration in animal models. ${ }^{33}$ We chose to develop the model in female C57BI/6 mice based on clinical evidences that point out women are more susceptible to emphysema development than men ${ }^{34}$ and on pre-clinical assays that demonstrated the higher susceptibility of female A/J mice to emphysema. ${ }^{35}$ The use of an appropriate model of emphysema is essential to investigate relevant questions involved in the pathophysiology of the disease and to test the therapeutic potential of new drugs. Another essential point is the use of methods to evaluate the physiological parameters of respiratory in the emphysema model.

Evaluation of pulmonary function and measurement of physiological parameters are crucial to studies that investigate new therapeutic strategies, pathogenesis of disease and toxicology. There are invasive and noninvasive pulmonary function tests available which are sensitive in detecting abnormalities in mechanical respiratory. The invasive methodology evolution allowed the evaluation of relevant parameters transpulmonary pressure, expiratory and inspiratory flows, such as pulmonary resistance and compliance. Although these procedures give precise data, they involve invasive surgical procedures ${ }^{23}$ (orotracheal intubated animal) and anesthesia that impose non-physiological conditions to experiment that may generate significant artifacts, such as decreased respiratory frequency, ${ }^{24}$ besides the risk of death of animals due to the procedure which implies the use of a larger number of animals per experimental group. The non-invasive methodology started in the end of $70 \mathrm{~s}^{25}$ and there are basically two types of plethysmograph: double-chamber and single-chamber whole-body instrument. This noninvasive serial measurements reduced the number of animal per study, but long-term examination is not allowed due to the stress imposed by of the neck collar restrained. Noninvasive techniques to evaluate respiratory parameters in conscious mice are easy, convenient, repetitive and reproducible, appropriate for quick and repeatable screening of respiratory function in a large number of conscious animals, ${ }^{26}$ however are not so accurate as the invasive method, and some important data about pulmonary function may be misleading.

This kind of evaluation is essential to reveal information about pulmonary function but does not provide data on the degree of impairment of physical capacity of the animal. Lüthje et al. ${ }^{27}$ demonstrated exercise intolerance by treadmill as a consequence of pulmonary emphysema and its systemic consequence in elastase-induced-emphysema model in transgenic mice.

Following this rational, we sought to evaluate a different procedure to establish experimental pulmonary emphysema in C57Bl/6 using elastase via tracheal puncture. To prove the efficacy of emphysema induction, we investigated the degree of impairment of physical capacity by the evaluation of respiratory function during exercise testing on treadmill, acquiring data about distance run, exercise time, oxygen consumption, and carbon dioxide production. To evaluate the structure alterations we measured LM, an objective parameter that represents the average distance between alveolar walls. The increase of $L m$ with age is relatively small and it is independent of body size. This measurement is easy to make and is independent of the observer. This measurement is considered to be suitable for detailed studies that aim to correlate structure and function disturbances in lungs. ${ }^{28}$

By the investigation of functional disturbances and structural alterations associated with elastase-induced emphysema in mice, we aimed to establish an experimental model with high reproducibility and low mortality. We analyzed safety, feasibility and reproducibility of our model applying intratracheally an intermediary dose of elastase to produce the enlargement of alveolar space and its consequences on respiratory function.

\section{Materials and methods}

\section{Animals}

Two-month old female C57Bl/6 mice $(n=36)$, weighing around $20 \mathrm{~g}$, raised and maintained at the animal facilities at the Gonçalo Moniz Research Center, FIOCRUZ, were used in the experiments, and were provided with rodent diet and water ad libitum. All animals were euthanized in a $\mathrm{CO}_{2}$ chamber, and handled according the NIH guidelines for ethical use of laboratory animals.

\section{Experimental groups}

The animals were randomly divided into three groups: $(A)$ control: non-manipulated animals $(n=12)$; (B) intratracheal elastase: $100 \mu \mathrm{l}(n=12)$; and $(C)$ intratracheal PBS $100 \mu \mathrm{l}$ $(n=12)$.

\section{Emphysema induction}

For elastase instillation, mice were anaesthetized with ketamine (Vetbrands) and atropine (Allergan), intubated 
orotracheally, and ventilated using a ventilator/respirator (Mini-Vent Small Animal Ventilators, Kent Scientific). Experimental animals received $2 \mathrm{U} / 100 \mathrm{~g}$ body weight porcine pancreatic elastase (Sigma, Aldrich, Taufkirchen, Germany) dissolved in $100 \mu \mathrm{l}$ phosphate-buffered saline (PBS)solution or $100 \mu \mathrm{l}$ PBS alone. Control animals were not manipulated.

The respective solution was administered intratracheally via tubing followed by $200 \mu \mathrm{l}$ of air for an even distribution of the liquid throughout both lungs. The animals were submitted to anterior cervical incision in order to visualize the trachea and make the tracheal puncture to administer one of the solutions. Afterwards, mice were sutured, kept on a warm plate $\left(30^{\circ} \mathrm{C}\right)$ until restoration of spontaneous breathing and then were extubated.

\section{Treadmill}

A motor-driven treadmill chamber for one animal (LE 8700, Panlab, Barcelona, Spain) was used to exercise the animals. The speed of the treadmill and the intensity in milliamps of the electric shock applied to an stainless steel grid at the rear end of the treadmill were controlled by a potentiometer (LE 8700 treadmill control, Panlab). Room air was pumped into the chamber at a controlled flow rate $(700 \mathrm{ml} / \mathrm{min})$ by a chamber air supplier (OXYLET LE 400, Panlab). Outflow was directed to an oxygen and carbon dioxide analyzer (Oxylet 00; Panlab) to measure consumption of oxygen and production of carbon dioxide. The mean room temperature was maintained at $21 \pm 1{ }^{\circ} \mathrm{C}$. After an adaptation period of $40 \mathrm{~min}$ in the treadmill chamber the mice were exercised at different velocities, starting at $7.2 \mathrm{~m} / \mathrm{min}$ and increasing the velocity $7.2 \mathrm{~m} / \mathrm{min}$ every $10 \mathrm{~min}$. The inclination of the treadmill was maintained at an uphill angle of $10^{\circ}$. Velocities were increased until the animal could no longer sustain a given speed and remained for more than ten seconds on the electrified grid, which provided an electrical stimulus (1 milliamp) to keep the mice running. Total running distance and running time were recorded. Treadmill tests were carried out on all mice before the induction of emphysema and 28 days after experimental procedures.

\section{Histopathological analysis}

Twenty-eight days after application of elastase or PBS, the mice were euthanized using $\mathrm{CO}_{2}$ and the lungs were exposed. The trachea was canullated with gelco number 18 and the lungs were perfused with buffered $4 \%$ formalin applying a constant transpulmonary pressure of $20 \mathrm{~cm} \mathrm{H}_{2} \mathrm{O}$ for $2 \mathrm{~h}$. After this procedure the trachea was sutured in order to hold the intrapulmonary pressure at $20 \mathrm{~cm} \mathrm{H}_{2} \mathrm{O}$ and the entire cardiopulmonary tissue block was removed and fixed in formalin (4\%).

Morphologic examinations were performed following Thurlbeck $^{28}$ method modified. Briefly, the mean linear intercept $(\mathrm{Lm})$ of each lung was determined using light microscopy on 20 randomly selected fields, originating from randomly selected tissue samples covering the entire lung and containing apical as well as basal areas of the organ. Five pictures were taken of each lung. The $L m$ as indicator of air space size was calculated from counting lines of defined length that were randomly placed on each of the 20
Table 1 Percentage of mortality related to different methodology to induce experimental pulmonary emphysema. (A) Control: non-manipulated animals; (B) intratracheal $100 \mu$ l of elastase administration; (C) intratracheal $100 \mu \mathrm{l}$ of saline administration.

\begin{tabular}{lllc}
\hline Group & Number of mice & Mortality & $\%$ \\
\hline A & 12 & 0 & 0 \\
B & 12 & 2 & 16.7 \\
C & 12 & 2 & 16.7 \\
Total & 36 & 4 & 11.1 \\
\hline
\end{tabular}

lung sections of $5 \mu \mathrm{m}$ and the number of intercepts crossing the lines counted. The $L m$ was calculated from the length of the lines multiplied by the number of the lines divided by the sum of all counted intercepts.

\section{Statistical analysis}

Numeric values were expressed as mean \pm SD unless stated otherwise. Treadmill performance was analysed using a paired $t$-test to compare groups before and after treatment and morphometric data were compared applying a One-way ANOVA followed by a Tukey test to identify groups that are significantly different. A value of $P<0.05$ was considered statistically significant.

\section{Results}

\section{Safety of the procedure - mortality}

Four out of 36 mice $(11.1 \%)$ died during the experimental procedure. The groups manipulated by intratracheal function showed a similar mortality (two death per group), independent of the kind of solution administrated (Table 1).

\section{Functional analysis - ergometry}

Maximum velocity and running distance reached by each group before (pre) and after (post) administration of PBS or elastase are summarized in Table 2.

Before the manipulation, all mice were capable of exercising on the treadmill. After manipulation, intratracheal elastase administration (group B) showed a significant decrease in the maximum exercise velocity being able to sustain treadmill velocities up to $15.1 \mathrm{~m} / \mathrm{min}$ (Table 2 ). These differences resulted in a significant reduction in distance covered by tracheal elastase-treated mice when compared to tracheal saline-treated mice, reducing running distance by $30.5 \%$ in the former group (Table 2 ).

Concerning oxygen consumption and carbon dioxide production, all mice treated with elastase increased oxygen consumption after induction when compared at the same speed before and after administration of elastase (Fig. 1A). In relation to the production of carbon dioxide, no significant difference was observed at the same speed before and after administration of elastase (Fig. 1B). 
Table 2 Mice performance during exercise on a motorized treadmill evaluated by maximum velocity reached and maximum distance covered before (pre) and after treatment (post) and the respective percentage change (\%). Groups as in Table 1.

\begin{tabular}{lllll}
\hline Group & \multicolumn{2}{c}{ Velocity $(\mathrm{m} / \mathrm{min})$} & \multicolumn{2}{c}{ Distance $(\mathrm{m})$} \\
\cline { 2 - 3 } & Pre & Post & Pre & Post \\
\hline A & $19.8 \pm 3.0$ & $19.2 \pm 3.2$ & $900 \pm 124$ & $810 \pm 173$ \\
B & $19.2 \pm 2.7$ & $16.2 \pm 3.1^{*}$ & $810 \pm 161$ & $570 \pm 45^{*}$ \\
C & $18.0 \pm 3.0$ & $18.0 \pm 3.6$ & $710 \pm 157$ & $720 \pm 201$ \\
\hline
\end{tabular}

* Indicates a value significantly lower after treatment $(P<0.05)$.

\section{Morphometric analysis - mean linear interseptum measurement}

The administration of $100 \mu \mathrm{l}$ of elastase by the tracheal route significantly increased $L \mathrm{~m}(99.6 \pm 2.9 \mu \mathrm{m})$ when compared to intratracheal saline-treated $(33.3 \pm 0.6 \mu \mathrm{m})$ and non-manipulated mice $(25.6 \pm 0.1 \mu \mathrm{m})$. A slight, but


Figure 1 Comparison of respiratory function during physical effort in mice before and after the administration of elastase. Oxygen consumption (A) and carbon dioxide release (B), during resting conditions, exercising at 5 different velocities (7.2, 14.4, 21.6, 28.8 and $36 \mathrm{~m} / \mathrm{min}$ ) on a motorized treadmill, immediately (Exhaustion) and $25 \mathrm{~min}$ after exercise (recovery). Data are means $\pm S D ; 10$ mice/group. Note that mice elastasetreated were unable to run at a velocity of $36 \mathrm{~m} / \mathrm{min}$; therefore, no data are given. ${ }^{*} p<0.05 ;{ }^{* *} p<0.01 ;{ }^{* * *} p<0.001$.



Figure 2 Comparison of the mean linear intercept length in three groups of $\mathrm{C} 57 \mathrm{Bl} / 6$ mice treated in $(\mathrm{A})$ non-manipulated animals $(n=12),(B)$ animals receiving tracheal elastase $(n=12)$, or $(C)$ receiving tracheal saline $(n=12)$. Data are presented as means \pm SD. * Indicates a significant difference $(P<0.05)$ between goups.

significant, increase in $L \mathrm{~m}$ was found comparing traqueal application of saline with non-manipulated animals (Fig. 2).

\section{Discussion and conclusion}

In this work we induced emphysema by intratracheal instillation of porcine pancreatic elastase, which resulted in a mean linear intercept of $99.6 \mu \mathrm{m}$. Ishizawa et al. ${ }^{29}$ applied the same concentration of elastase by intranasal instillation to induce the experimental emphysema in mice and, after three weeks, they observed pulmonary abnormalities and a mean linear intercept of $80 \mu \mathrm{m}$. The same group repeated the same procedure in order to test the effects of Hepatocyte Growth Factor in injured lungs by elastase, but the mean linear intercept was slightly smaller: $65 \mu \mathrm{m} .{ }^{30}$ Another study, ${ }^{31}$ using both C57BL/ 6 mice and SP-C/TNF-a transgenic mice, using similar dosage of elastase found a mean linear intercept ranging between 60 and $85 \mu \mathrm{m}$. Comparing these morphometric data suggests that intratracheal administration of elastase seems more efficient to induce emphysema, coupled with a relatively low mortality. The experimental procedures used in our study to induce emphysema can be considered tolerable since the mortality index in all experimental groups remained low (Table 1). Ishizawa et al. ${ }^{29,30}$ did not mention the mortality rate observed in their studies. 
Recently, ${ }^{27}$ emphysematous disturbances were induced in a transgenic strain of mice (NMRI), which possesses a higher endogenous anti-protease activity. Two experimental groups were used to administer porcine pancreatic elastase by intratracheal instillation: $5 \mathrm{U} / 100 \mathrm{~g}$ body weight, single administration and $3.3 \mathrm{U} / 100 \mathrm{~g}$ body weight, repetitive administration. In both treatments the absolute mortality of animals was much higher than that in our work (six and five mice, respectively). However, the authors do not mention the total number of animals used per group, but it seems clear that the higher concentrations of elastase used in their study resulted in a greater mortality rate among experimental animals when compared to the present study. ${ }^{27}$ These results indicate that the experimental protocol used in our study is more applicable to induce emphysema in mice.

Comparing the morphological parameters of our study with the ones measured by Lüthje et al. ${ }^{27}$ we observed that the $L \mathrm{~m}$ was greater in the latter study $(260.7 \mu \mathrm{m})$ when compared to our data $(99.6 \mu \mathrm{m})$. The greater destruction of lung parenchyma induced in the mice by Lüthje et al. ${ }^{27}$ can be attributed to the greater concentration of elastase used, as well as to the mouse strain used, which is more susceptible to the development of pulmonary structure abnormalities.

The physical activity is significantly impaired in many patients with COPD, significantly altering their quality of life. The pathogenesis of physical incapacity is complex and involves loss of respiratory muscle strength, changes in gas exchange, and abnormalities in lung mechanics, which reflects in exercise intolerance that is a direct consequence of impairment in respiratory mechanics. However, the measurement of parameters related to respiratory mechanics involved invasive or noninvasive methodology, which it is not totally secure, requiring a large number of animals to be used or a loss of accuracy of measurements of respiratory parameters, since it does not reflect the physiological reality of an undisturbed animal. The invasive measurements require that animals are anesthetized and ventilated, ${ }^{23}$ orotracheally or endotracheally intubated, tracheotomized ${ }^{32}$ or under spontaneous breathing. The advantages of these methods include no stress for the animal and the evaluation of gold standard parameters, such as resistance and compliance. However, the anesthesia could alter some physiological parameters and depending on methodology the measurement cannot be repeated. ${ }^{33}$ Hantos et al. ${ }^{34}$ tried to establish a link between the mechanical properties of the respiratory system and absolute lung volumes in elastase-induced emphysema in order to investigate how these physiological findings are related to the pathophysiological changes in lung volumes and the associated alterations in respiratory resistance and elastance in patients. Thus, the tissue damage did not correlate with airway dysfunction in this mouse model of emphysema. ${ }^{34}$

On the other side, noninvasive techniques are easy to perform, allow spontaneously breathing, and can be done in large numbers of conscious animal during the same period. As previously mentioned, there are two types of plethysmograph: double-chamber and single-chamber whole-body instruments. In the first one the animal is restrained at the neck. The animals are placed in the body plethysmograph, while the head protruded through a neck collar into a ventilated head exposure chamber. ${ }^{35,36}$ This apparatus which is attached to an amplifier is connected to a pneumotachograph and a differential pressure transducer, which allows airflow measurement, tidal volume, minute volume and respiratory rate. ${ }^{37}$ These noninvasive serial measurements reduced the number of animal per study, but long-term examination is not allowed due to the stress imposed by the neck collar restrained. There is also a unrestrained double-chamber instrument where the animal's head and body are separated in a chamber by a rubber collar around the neck, which creates two environments: nasal chamber and thoracic chamber. In single-chamber whole-body plethysmograph, no restraint is required and the animals have free access to water and food. These recordings may be done all day long but physiological measurement is indirect since it is done based on pressure changes in single-chamber whole-body plethysmograph. ${ }^{38}$ The results are reproducible despite of the chamber plethysmograph employed. The single-chamber is appropriate to measure airway resistance reactivity to drug administration, but not to evaluate tidal volume. On other side, the double-chamber is to provide accurate results about tidal volume and respiratory rate. ${ }^{37}$ When this technique is performed in a double chamber with restrained animal records of inspiratory and expiratory flows, tidal volume, minute volume and respiratory rate can be done directly, but it is not possible to measure transpulmonary pressure or airway resistance. The noninvasive measurements with unrestrained animal in a single chamber allow physiological measurement based on pressure alterations inside the chamber, thus the inspiratory and expiratory flows are evaluated indirectly, and the transpulmonary pressure cannot be analyzed. The limitation is the shortage of accuracy on the evaluation of physiological parameters, such as respiratory rate and tidal volume. ${ }^{39}$

In addition to the reasons described above, that justify the use of treadmill exercise to assess the functional limitations of the respiratory system induced by emphysema, ${ }^{29-31}$ there is the fact that acute physical exercise is known to markedly increase the blood flow and oxygen uptake in the lung. The severity of pulmonary parenchyma lesions on exercise performance can be easily evaluated by ergometric tests, and in experimental models of emphysema this fact may be evaluated by testing exercise capacity in treadmill, as performed by Lüthje et al. ${ }^{27}$ which demonstrated a reduction in relative run distance in emphysematous mice. Here, not only the distance run and exercise time were measured but the consumption of oxygen and carbon dioxide were evaluated. The results obtained demonstrated that emphysema induction committed the exercise capacity probably due to an impairment in gas exchange (Fig. 1 and Table 2).

In our work, with a single intratracheal administration of elastase and a small degree of inclination in the treadmill, we observed a reduction in running distance of $30.5 \%$ when compared to pre-treatment exercise capacity of emphysematous mice. The greatest decrease in maximum velocity was also seen in the group treated with elastase by intratracheal route (Table 2 ). A reduction in maximum velocity during treadmill exercise was also observed in a rat model of emphysema after intratracheal administration of elastase. ${ }^{34}$ The treadmill performance of mice in the study by Lüthje and co-workers revealed that there was no difference in running distance between control and single intratracheal administration of elastase groups, whereas the reduction in 
running distance in the group with repetitive intratracheal administration of elastase was $29.7 \%$. Therefore, although the pulmonary tissue destruction was more severe in the study by Lüthje and co-workers, as shown by liner intercept length, probably due to strain susceptibility and the number of elastase administration, our experimental procedure resulted in the same level of serious functional impairment, as revealed by the exercise performance. Different from the previous works, we analysed the dynamics of gas exchange during exercise. The augment in oxygen consumption (Fig. 1A) could reflect the ability of the heart to increase cardiac output in order to attend the metabolic demands of animal during physical effort, trying to hold the blood oxygen partial pressure in the face of blood carbon dioxide partial pressure altered. The maintenance of carbon dioxide production (Fig. 1B) could mean the impairment of gas exchange. These respiratory dysfunction is reflected in a lower exercise capacity and could be consequence of pulmonary parenchyma lesion.

Up to date, all of the studies inducing emphysema in animal models are insufficiently capable of reproducing the slow and progressive inflammatory process that leads to chronic pulmonary injury in humans. However, they helped to elucidate the pathogenic mechanisms and the development of new clinical therapeutic protocols. Different animals such as hamsters, rats, and mice were used to establish models of emphysema, which are based on genetic manipulations (in mice), exposure to cigarette smoke, or administration of proteinases into the airway. Knockout or transgenic mice models for emphysema revealed different genes that could be involved in the pathogenesis of emphysema, such as platelet derived growth factor $A,{ }^{40}$ fibroblast growth factor receptors 3 and $4,{ }^{41}$ metalloproteinase1 transgenic mice, ${ }^{15}$ platelet derived growth factor B transgenic mice, ${ }^{42}$ macrophage elastase, ${ }^{43}$ and neutrophil elastase, ${ }^{44}$ the last ones given resistance to smoke-induced emphysema. However, it is noteworthy that these genetargeted mice may have alterations in lung structure, such as alveolar enlargement, possibly associated to alterations in lung development instead of emphysema development due to destruction in pulmonary parenchyma, since these genes are expressed throughout the tissue development, growth, and maturation. ${ }^{45}$ The smoke-induced animal models of COPD include nose-only exposure or whole body exposure. This model may be developed in different animal species, such as rat, ${ }^{46}$ guinea-pig, ${ }^{47}$ or mouse. ${ }^{48}$ The guinea-pig reproduces the most appropriate model of emphysema, but there are many problems related to the cost, shortage of tools to investigate molecular mechanisms, and reduced number of reagent specific to this animal species. ${ }^{4,49}$ Rats are very resistant and if the time and volume of smoke exposure are extrapolated these animals developed in specific abnormalities. ${ }^{50}$ With regards to mice, in addition to the advantages described above, functional parameters such as compliance, can be accurately measured. ${ }^{4}$ However, the smoke-induced-emphysema model is not so reproductible, ${ }^{51,52}$ the time for developing the disease is long (about six months), produce only a mild disease and after the cessation of smoke the lesions do not appear to progress. ${ }^{4}$ Currently, mice are considered the gold standard to reproduce and study many human diseases, since the mouse genome shows a great similarity to the human genome, having about 300 genes uniquely present in one species or the other. ${ }^{53}$ Furthermore, more than 10,000 genetic markers have been mapped in the mouse, a large number of inbred strains and transgenic mice are available, and data on the animals' anatomy, biology, immunology, and physiology are available.

The model tested in our study provides some advantages, including the use of a lower elastase concentration when compared to other studies. Nonetheless, it induced severe structural abnormalities that may be responsible for functional disturbances characterizing pulmonary emphysema. Furthermore, the emphysema could be induced with a very low mortality rate and a high degree of reproducibility, which could be functional analyzed by non-invasive technique that reflects the physical impairment associated to structural abnormalities characteristic of pulmonary emphysema.

\section{Conflicts of interest}

The authors have no conflicts of interest to declare.

\section{Acknowledgements}

This work was supported by grants from the Brazilian Ministry of Science and Technology, CNPq, FINEP, FIOCRUZ, and FAPESB.

\section{References}

1. Chen ZH, Kim HP, Ryter SW, Choi AMK. Identifying targets for COPD treatment through gene expression analyses. Int J COPD. 2008;3:359-70.

2. Warburton D, Gauldie J, Bellusci S, Shi W. Lung development and susceptibility to chronic obstructive pulmonary disease. Proc Am Thorac Soc. 2006;3:668-72.

3. Ohnishi S, Nagaya N. Tissue regeneration as next-generation therapy for COPD-potencial applications. Int J COPD. 2008;3:509-14.

4. Wright J, Cosio M, Chung A. Animal models of chronic obstructive pulmonary disease. Am Physiol Soc. 2008.

5. Pinckerton KE, Dodge DE, Cederdahl-Demmier J, Wong VJ, Peake J, Haselton CJ, Mellick PW, Singh G, Plopper CG. Differentiated bronchiolar epithelium in alveolar ducts of rats exposed to ozone for 20 months. Am J Pathol. 1992;142:947-56.

6. Gross P, Pfitzer EA, Tolker E, Babyak MA, Kaschak M. Experimental emphysema: its production with papain in normal and silicotic rats. Arch Environ Health. 1965;11:50-8.

7. Gross P, Pfitzer E, Tolker M, et al. Experimental emphysema: its production with papain in normal and silicotic rats. Arch Environ Health. 1965;11:50-8.

8. Lafuma C, Frisdal E, Harf A, Robert L, Hornebeck W. Prevention of leucocyte elastase-induced emphysema in mice by heparin fragments. Eur Respir J. 1991;4:1004, 9.

9. Hernandez JA, Anderson Jr AE, Holmes WL, Foraker AG. Macroscopic relations in emphysematous and aging lungs. Geriatrics. 1966;21:155-66.

10. March TH, Barr EB, Finch GL, Hahn FF, Hobbs CH, Ménache MG, Nikula KJ. Cigarette smoke exposure produces more evidence of emphysema in B6C3F1 mice than in F344 rats. Toxicol Sci. 1999;51:289-99.

11. Aoshiba K, Yokohori N, Nagai A. Alveolar wall apoptosis causes lung destruction and emphysematous changes. Am J Respir Cell Mol Biol. 2003;28:555-62. 
12. Blackwood RA, Cerreta JM, Mandl I, et al. Alpha 1-antitrypsin deficiency and increased susceptibility to elastase-induced experimental emphysema in a rat model. Am Rev Respir Dis. 1979;120:1375-9.

13. O’Donnell MD, O'Connor CM, FitzGerald MX, Lungarella G, Cavarra E, Martorana PA. Ultrastructure of lung elastin and collagen in mouse models of spontaneous emphysema. Matrix Biol. 1999;18:357-60.

14. Wendel DP, Taylor DG, Albertine KH, Keating MT, Li DY. Impaired distal airway development in mice lacking elastin. Am J Respir Cell Mol Biol. 2000;23:320-6.

15. D'Armiento J, Dalal SS, Okada Y, et al. Collagenase expression in the lungs of transgenic mice causes pulmonary emphysema. Cell. 1992;71:955-61.

16. Harada H, Imamura M, Okunishi K, Nakagome K, Matsumoto T, Sasaki O, Tanaka R, Yamamoto K, Dohi M. Upregulation of lung dendritic cell functions in elastase-induced emphysema. Int Arch Allergy Immunol. 2009;149 Suppl 1:25-30.

17. Valentine R, Rucker RB, Chrisp CE, Fisher GL. Morphological and biochemical features of elastase-induced emphysema in strain A/J mice. Toxicol Appl Pharmacol. 1983;68:451-61.

18. Hamakawa H, Bartolák-Suki E, Parameswaran H, Majumdar A, Lutchen KR, Suki B. Structure-function relations in an elastaseinduced mouse model of emphysema. J Am J Respir Cell Mol Biol. 2011;45:517-24.

19. Ito S, Ingenito EP, Arold SP, Parameswaran H, Tgavalekos NT, Lutchen KR, Suki B. Tissue heterogeneity in the mouse lung: effects of elastase treatment. J Appl Physiol. 2004;97:204-12.

20. Groneberg D, Chung FK. Models of chronic obstructive pulmonary disease. Respir Res. 2004;5:18.

21. Martinez FJ, Curtis JL, Sciurba F, Mymford J, Giardino ND, Weinmann G, Kazerooni E, Murray S, Criner GJ, Sin DD, Hogg JC, Ries AL, Han M, Fishman AP, Make G, Hoffman EA, Mohsenifar Z, Wise R, National Emphysema Treatment Trial Research Group. Sex differences in severe pulmonary emphysema. Am J Respir Crit Care Med. 2007;176:243-52.

22. March TH, Wilder JA, Esparza DC, Cossey PY, Blair LF, Herrera LK, MCDonald JD, Campen MJ, Mauderly JL, Seagrave J. Modulators of cigarette smoke-induced pulmonary emphysema in $\mathrm{A} / \mathrm{J}$ mice. Toxicology. 2006;92:545-59.

23. Amdur MO, Mead J. Mechanics of respiration in unanesthetized guinea pigs. Am J Physiol. 1958;192:364-8.

24. Drazen JM, Finn PW, De Sanctis GT. Mouse models of airway responsiveness: physiological basis of observed outcomes and analysis of selected examples using these outcome indicators. Annu Rev Physiol. 1999;61:593-625.

25. Pennock BE, Cox CP, Rogers RM, Cain WA, Wells JH. A noninvasive technique for measurement of changes in specific airway resistance. J Appl Physiol. 1979;46:399-406.

26. Glaab T, Ziegert $M$, Baelder $R$, Korolewitz $R$, Braun A, Hohlfeld JM, Mitzner W, Krug N, Hoymann HG. Invasive versus noninvasive measurement of allergic and cholinergic airway responsiveness in mice. Respir Res. 2005;6:139.

27. Lüthje L, Raupach T, Michels H, Unsöld B, Hasenfuss G, Kögler $\mathrm{H}$, Andreas $\mathrm{S}$. Exercise intolerance and systemic manifestations of pulmonary emphysema in a mouse model. Respir Res. 2009;10:7-17.

28. Thurlbeck WM. Internal surface area of normal and emphysematous lungs. Aspen Emphysema Conf. 1967;10:379-93.

29. Ishizawa K, Kubo H, Yamada M, Kobayashi S, Numasaki $M$, Ueda S, Suzuki T, Sasaki H. Bone marrow-derived cells contribute to lung regeneration after elastase-induced pulmonary emphysema. FEBS Lett. 2004;556:249-52.

30. Ishizawa K, Kubo H, Yamada M, Kobayashi S, Suzuki T, Mizuno S, Nakamura T, Sasaki H. Hepatocyte growth factor induces angiogenesis in injured lungs through mobilizing endothelial progenitor cells. Biochem Biophys Res Commun. 2004;324:276-80.
31. Fujita $M$, Ye Q, Ouchi $H$, Nakashima $N$, Hamada N, Hagimoto $N$, Kuwano K, Mason RJ, Nakanishi Y. Retinoic acid fails to reverse emphysema in adult mouse models. Thorax. 2004;59: 224-30.

32. Palecek F, Palecekova M, Aviado DM. Emphysema in immature rats. Condition produced by tracheal constriction and papain. Arch Environ Health. 1967;15:332-42.

33. Hoymann HG. New developments in lung function measurements in rodents. Exp Toxicol Pathol. 2006;57. S2: 5-S2:11.

34. Hantos Z, Adamicza A, Jánosi TZ, Szabari MV, Tolnai J, amd Suki B. Lung volumes and respiratory mechanics in elastaseinduced in mice. J Appl Physiol. 2008;105:1864-72.

35. Glaab T, Daser A, Braun A, Neuhaus-Steinmetz U, Fabel H, Alarie $\mathrm{Y}$, Renz $\mathrm{H}$. Tidal midexpiratory flow as a measure of airway hyperresponsiveness in allergic mice. Am J Physiol Lung Cell Mol Physiol. 2001;280:L565-73.

36. Glaab T, Hoymann HG, Hohlfeld JM, Korolewitz R, Hecht M, Alarie Y, Tschernig T, Braun A, Krug N, Fabel H. Noninvasive measurement of midexpiratory flow indicates bronchoconstriction in allergic rats. J Appl Physiol. 2002;93:1208-14.

37. DeLorme MP, Moss OR. Pulmonary function assessment by wholebody plethysmography in restrained versus unrestrained mice. J Pharmacol Toxicol Methods. 2002;47:1-10.

38. Drorbaugh JE, Fenn WO. A barometric method for measuring ventilation in newborn infants. Pediatrics. 1955;16:81-7.

39. Shigemura N, Okumura M, Mizuno S, Imanishi $Y$, Nakamura T, Sawa Y. Autologous transplantation of adipose tissue-derived stromal cells ameliorates pulmonary emphysema. Am J Transplant. 2006;6:2592-600.

40. Boström $H$, Willetts $K$, Pekny $M$, Levéen $P$, Lindahl $P$, Hedstrand $H$, Pekna $M$, Hellström $M$, Gebre-Medhin $S$, Schalling M, Nilsson M, Kurland S, Törnell J, Heath JK, Betsholtz C. PDGF-A signaling is a critical event in lung alveolar myofibroblast development and alveogenesis. Cell. 1996;85:863-73.

41. Weinstein $M, X u X$, Ohyama K, et al. FGFR-3 and FGFR-4 function cooperatively to direct alveogenesis in the murine lung. Development. 1998;125:3615-23.

42. Hoyle GW, Li J, Finkelstein JB, et al. Emphysematous lesions, inflammation, and fibrosis in the lungs of transgenic mice overexpressing platelet-derived growth factor. Am J Pathol. 1999;154:1763-75.

43. Hautamaki RD, Kobayashi DK, Senior RM, Shapiro SD. Requirement for macrophage elastase for cigarette smoke-induced emphysema in mice. Science. 1997;277: 2002-4.

44. Shapiro SD. Animal models for COPD. Chest. 2000;117:223-7.

45. Mahadeva R, Shapiro SD. Chronic obstructive pulmonary disease: experimental animal models of pulmonary emphysema. Thorax. 2002;57:908-14.

46. Huh JW, Kim SY, Lee JH, Lee JS, Van Ta Q, Kim M, Oh YM, Lee YS, Lee SD. Bone marrow cells repair cigarette smokeinduced emphysema in rats. Am J Physiol Lung Cell Mol Physiol. 2011;301:L255-66.

47. Churg A, Marshall CV, Sin DD, Bolton S, Zhou S, Thain K, Cadogan EB, Maltby J, Soars MG, Mallinder PR, Wright JL. Late intervention with a myeloperoxidase inhibitor stops progression of experimental COPD. Am J Respir Crit Care Med. 2011.

48. Van Eijl S, Mortaz E, Ferreira AF, Kuper F, Nijkamp FP, Folkerts G, Bloksma N. Humic acid enhances cigarette smokeinduced lung emphysema in mice and IL-8 release of human monocytes. Pulm Pharmacol Ther. 2011.

49. Wright JL, Tai H, Churg A. Vasoactive mediators and pulmonary hypertension after cigarette smoke exposure in the guinea pig. J Appl Physiol. 2006;100:672-8.

50. Stevenson CS, Doex C, Webster R, Battram C, Hynx D, Giddings J, Cooper PR, Chakravarty P, Rahman I, Marwick JA, Kirkham PA, Charman C, Richardson DL, Nirmala NR, 
Whittaker P, Butler K. Comprehensive gene expression profiling of rat lung reveals distinct acute and chronic responses to cigarette smoke inhalation. Am J Physiol Lung Cell Mol Physiol. 2007;293:L1183-93.

51. Churg A, Cosio M, Wright JL. Mechanisms of cigarette smokeinduced COPD: insights from animal models. Am J Physiol Lung Cell Mol Physiol. 2008;294:L612-31.
52. Guerassimov A, Hoshino Y, Takubo Y, et al. The development of emphysema in cigarette smoke-exposed mice is strain dependent. Am J Respir Crit Care Med. 2004;170: 974-80.

53. Waterston RH, Lindblad-Toh K, Birney E. Initial sequencing and comparative analysis of the mouse genome. Nature. 2002;420:520-62. 